\title{
The Western Voice and Feminist Criticism of the Nigerian Novel
}

\author{
Jonas Egbudu Akung ${ }^{1, *}$ \\ ${ }^{1}$ Department of English and Literary Studies, University of Calabar, P.M.B 1115, Nigeria \\ *Correspondence: Department of English and Literary Studies, University of Calabar, P.M.B 1115, Nigeria \\ Tel: 234-803-706-3754Ｅ-mail: Jonduke2007@yahoo.com
}

Received: December 6, 2012 Accepted: January 14, $2013 \quad$ Online Published: January 22, 2013

doi:10.5430/wjel.v3n1p24

URL: http://dx.doi.org/10.5430/wjel.v3n1p24

\begin{abstract}
The Western voice is one of the pioneering voices in the early development of the feminist criticism of the Nigerian novel. As a result it constantly deploys Western critical methods into the criticism of the Nigerian Novel .This paper therefore re-examines these issues using meta-criticism in order to put the feminist ideology in proper perspective in the Nigerian Novel. The feminist ideology in the Nigerian Novel tends to reduce Africa to cultural satellite of Europe. The attempts by the practitioners of feminist theory to define and align themselves with the theory have produced many strands of the same theory. Among these strands are: feminism, motherism, womanism among others, all in an effort to remain African and still relevant within the global perspectives. The paper discusses Western feminist critics' views on the Nigerian novel. The paper concludes that though the theory is gaining wide acclaim in Nigeria, what this paper advocates is womanism which is accommodative, complimentary and non-radical in its approach
\end{abstract}

Keywords: western voice; criticism; Nigerian novel; theory, feminism, womanism motherism

\section{Introduction}

Feminist criticism, over the years, has made concerted attempts at developing theories that could establish differences in gendered reading of texts. For instance, Elaine Showalter (1985:3) argues that:

... feminist criticism developed as part of the international

women's movement ... feminist criticism has shown that women readers and critics bring different perceptions and expectations to their literary experience, and has insisted that women have also told important stories of our culture.

Showalter here outlines the basic tenets of feminist criticism. She is of the view that in the past the story was told by the male and the interpretation was done by male critics. Even when the story was told by women the interpretation of the story was done by men. It is now the place of women to interpret their own stories and to re-read the male texts, thereby giving the male story a gendered interpretation. It is also an attempt to outline feminist differences in textual reading. Feminist criticism has not only helped in guarding the bastions of male intellectual endeavour, but it has also helped to open a space for the authority of the female critic which goes beyond women writings to the whole body of texts. It will be of interest to note that of all theories, it is only the feminist theory that does not look back to any previously existing theory. For instance, the structuralist theory will be linked to the linguistic discoveries of Saussure, the Psychoanalytic to Freud, the Marxist to "Des Kapital" and Deconstruction to Derrida etc. Feminist critics have studied all these theories, and they use them as analytical tools for feminist criticism. Though the feminist movement has been in existence for the last four decades, a definition that will reduce it to a single digit is yet in sight. However the unifying factor is gender consciousness. The text, that is the individual text, will reveal its own form and pattern, influence and structure. Its tenet is not exclusively female, its history and expression are linked up to gender.

Feminist criticism came to maturity with the publication of Kate Millett's Sexual Politics (1970). Earlier, in the U.S., literary as well as academic women writers, editors and graduate students who took part in the women's liberation movement of the 1960s prompted the birth of feminism. With the publication of Millett's book, there was a great awakening which necessitated the rediscovery of the female texts in the novel genre. With the rediscovery of the text, women critics started exposing the negative image in these texts which also fashioned the idea of discovering women 
writers and the feminist aesthetic in their works. The feminist aesthetic logically celebrates female consciousness. This aesthetic is manifest in the works of such writers as Alice Walker, Toni Morrison, Maya Angelou, Bessie Head, Buchi Emecheta Akachi Ezeigbo, Flora Nwapa as well as in the works of younger female writers like Chimamanda Adichie, Promise Okekwe and others.

Annette Kolodny (1985: 47) argues that the dominance of feminist criticism is so because it has provoked further readings of once-read texts: "A critic is strong if his readings similarly provoke other readings". This position agrees with the views of Barbara Smith (1985:68) when she argues that the criticisms of feminist writings have been done by males in the past and the rise of feminist criticism to her "seems overwhelming because it involves breaking such a massive silence". This massive silence has been broken in the last decades both in the West and in Africa. Smith has also added her voice to the rise of feminist criticism. She argues that "the existence of a feminist movement has an essential precondition to the growth of feminist literature, criticism, and women's studies which focused at the beginning almost entirely upon investigation of literature" (169). She commends the women's movement and the politics of sex as some of the factors that gave birth to feminist literary studies.

Susan Gubar (1985:293) posits that what led to feminist writing and criticism was culture. According to her "our culture is steeped in such myths as male primacy in theological, artistic and scientific and creative endeavours". She cites feminist theologians who have shown that power is based on God the Father, and early writers who use terms or male titles such as Priest, Prophets, Legislator, Emperor to describe the man. She refutes the idea of the Nory and Mud girls for they are products of a male imagination, which Simone de Beauvoir explicitly explained in her book, The Second Sex (1974). Gubar also raises such issues as "pen-penis writing" (295) which according to her modeled the long tradition that identified the author as male. The female image as seen in male authored works is merely a creation of the male imagination.

In her own view, Maggie Humm (1986:4) argues that "the growth of the feminist movement itself is inseparable from feminist criticism. Women become feminists by becoming conscious of, and criticizing the power of symbols and the ideology of culture". Humm acknowledges that feminist criticism is the brain daughter of the feminist movement. She cites Kate Millett's Sexual Politics (1971) which uses literary criticism to attack patriarchy. Humm is of the view that what marks feminist criticism is not mere attention to women writers, but also space for women critics and theorists to redress the "devaluation of women critics by men" (6). She outlines the major assumptions that define feminist criticism which include: literature and ideology, these are gender-related issues. She posits that critical methods invented by male critics may not be totally wrong, but they must be located within the larger context of the textual system. Reading the work of women does not make one a feminist critic, because some women will read as men. Humm argues for the need for "woman to read as woman" (13) is what defines feminist criticism. On the other hand, she does not share the view of men's reading as feminist. The main thrust of her view is that men do not feel the same pains as women.

The foremost works of feminist criticism are de Beauvoir's The Second Sex (1974), Kate Millett's Sexual Politics (1971), Betty Friedan's The Feminine Mystique, Germaine Greer's The Female Eunuch. These writers have made efforts to raise issues that have become fundamental in feminist criticism. de Beauvoir, for instance, asks why the woman is misrepresented in the male texts; Millett wonders what sexual politics is all about, and how it is represented in literature. Friedan and Greer ponder on why women will accept certain stereotypes. These issues have become central to feminist criticism.

Elisabeth Schussler Fiorenza (1998:3) argues that:

Although there are so many divergent forms and even contradictory articulations of feminism today that it is appropriate to speak of 'feminism' in the plural, most agree that contemporary feminism is not only a political movement akin to other emancipatory movements but also an intellectual methodology for investigating and theorizing the experience and structure of wo/men's oppression....

feminism is the radical notion that women are people.

She argues that "wo/men as people" situate is feminism within a "radical democratic discourse that argue for the right and wellbeing of all people without exception" (4). Fiorenza attempts also to locate feminism within a theological scope. She argues that "theological feminism understands women as people of God and indicts the death-dealing powers of oppression as a structural sin and life destroying evil" (4).

It is important to note that even when Fiorenza talks of theology, she limits it to Christian theology and fails to examine the role played by women in other religions in order to balance her argument. What she has done is to 
reform the study of the Bible giving it a feminist interpretation with the sole aim of giving women what she calls "full citizenship" (4).

Fiorenza further argues that many feminist critics have failed to adopt a proper typology for feminist criticism, and whatever is seen in journals is merely the new wine in the old wine skins of male theories. Her position is that, for feminism to get out of the confines of male theories, there is a need to redefine feminism and locate it theologically. Thus, according to her, the male critics have been insisting that a "feminist work must be measured by the prevailing intellectual standards of excellence" (45). Theological feminism has now become one of the succinct efforts by female critics to react to the feminist theory. The effort of theological feminists has given birth to such works as The Woman's Bible edited by Elizabeth Cady Stanton. Where the Bible is seen as "a sacred book that has sanctioned oppression"(52). The submission of theological feminist critics is the desire to search the female image of the Divine both in religion and in literature.

On the other hand, Marigit Eichler(1980:9) argues that feminism as it is seen today has double standard. This double standard may be seen in the kind of roles that are ascribed to the sexes. Therefore "feminist efforts are geared towards the abolition of sex roles and dysfunctions". The alternatives, for her are not going to be easy, because to make these alternatives one will need "to abolish sex roles ... coerce women and men to do jobs which neither of them wanted" (14). And since these roles cannot be abolished and the continued measuring of two things which are the same, but evaluated differently, is what she sees as a double standard.

For this double standard to be eliminated, feminist critics argue that the woman needs to be emancipated from her present position and accept the challenge. It is this emancipation that is the major thrust of the feminist theory. This emancipation, according to Eichler will begin from the abolition of roles according to sex. Eichler cited instances where height is used as a criterion for enlisting people into the force, because biologically it favours men. According to her, height is not a precondition for being a good police officer. It is mere double standard.

For the woman to be emancipated there should be a total elimination of all forms of discrimination against prostitution. Eichler argues that men have ascribed such terms as "good sex" and "bad sex". Good when done with your wife, bad when done with a woman whom you pay for such services. She says "sex for money is business" (127) and should not be shameful. She argues why it should be bad for women who render the service and not bad for men who create these prostitutes, and prostitution? According to her this constitutes the double standard which allows different degrees of sexual freedom for men and women. Ironically she argues that there is nothing like rape. According to her, rape appears as "a sexual act ... that is freely engaged in by both sexes. An older woman is not guilty of rape when she seduces a boy..." (129). Eichler's position is that feminism is merely concerned with the elimination of the double standard that exists between the sexes.

The feminist movement in Russia has different dimensions compared to Western feminism. In Russia the focus of feminist criticism is on social, political and economic issues, and not so much on the creative and literary.

According to Tatyana Mamonova (1984: xiii), the feminist movement in Russia attempts to "address issues of interest to all women. Unlike Eichler who argues that rape is not done by males alone, Mamonova holds that rape should be condemned and women compensated. While other feminist critics condemn abortion, she argues that the woman should have the right to choose to become a mother or not. She puts it vehemently thus: "I do not consider abortion bad ..." (xix).The argument by Western critics that the foetus has the right to live is seen by Mamonova as hypocritical.

Russian feminism arose to emancipate the Russian woman, who, according to Mamonova has been educated in falsehood, and to be brought to the true equality of the sexes. Mamonova puts it thus "the feminist movement in the Soviet Union is not a monolith; it comprises different philosophies and branches. There is a left wing... a non-nationalistic tendency is peculiar to the right wing, which comprises Russian Orthodox women" (women in Russia: xx). In spite of the differences in philosophies, these brands of feminism have been united for the common goal of emancipating the woman. The socialist conditions in which these women find themselves have made the brand of feminism in Russia more radical than others.

In the visual arts, the female gender is seen as visible. As Gloria Feman Orenstein (1988:159) puts it, "Artists who are in touch with the archetype of the goddess are now using the female form in both image and ritual as instrument of knowledge". In her view, Kathy Myers (1988:284)) calls for feminist eroticism as a means of asserting the feminist value of self. She calls for women to make a total withdrawal from hetro-sexual relationships. According to her, the specialist method shows that women can now "have the power to positively establish a separate identity". This group has developed into another major group known as libertarians. Libertarianism sees "the eroticism in 
pornography ... as liberating, symbolizing the life giving forces of love, pleasure, desire, etc" (Meyer:288). The tenet of Myers' position is that pornography, and eroticism which is its product, will help the woman strike a sexual and power balance.

The use of erotica as a means of asserting self got to a higher degree with Naomi Wolf (1997:181). She argues that in watching erotic pictures, a woman becomes sexually awakened:

the awakening of girls to erotic fulfillment is not a bashy and titillating cliché of material aimed at objectifying women for the consummation of thoughtless men, but a poignant tale of female coming of age that, if negotiated successfully, brings wellbeing to all.

Female erotica has been seen by her as a means for the woman's struggle for selfhood and womanhood. She dismisses such words as "slut". According to her, a woman who does not exploit her sexual apparatus to her own advantage may die socially, because "the death of the woman may be the shadow of her own desire" (Wolf:182).

Wolf attacks some of the things she refers to as male imaginations. According to her, men coin all sorts of derogatory words that overtly suggest that women are sex objects, prostitutes and are depraved. Most of these words refer to the female genital and the coital exercise. Wolf explains that sexual starvation for the woman poses a health threat and recommends that a woman under fifty years should be satisfied by her husband at least once in every five days (Wolf: 182). She dismissed clitoridectomy as bad as it reduces sexual pleasure in women. The baseline of Wolf's position is that women the world over have been using promiscuity as a secret weapon in the battle for womanhood. The practice of feminist criticism in the West has been on for a long time. Steven Lynn (1994:193) observes that: "feminist criticism arose to identify and oppose the various ways women are excluded, suppressed and exploited".

Feminist criticism identifies these areas of female oppression and exclusion, exposing them in feminist literary criticism. This takes place in the explication of literary texts to see how these vices are meted on women. In the creation of literary texts, feminist writers (mostly women) create characters that become the speaking voices of the women. In their creation of these characters women who were once voiceless could now voice their feelings. The dominance of feminist literary criticism has made Lynn to declare "that the future of literary studies is being decided in current feminist theory and criticism" (Lynn: 149). Indeed, critics like Elaine Showaltter have gone a step further to argue that feminist criticism can only be done by the women, and not by men who disguise as feminists. Showalter calls this "gyno-criticism", the study of women by women.

In his own view, Charles E. Bressler (1994:103) holds that the goal of feminism 'is to change the degrading view of women". Feminist writers have declared that the woman must be clearly defined in politics, society, education, and she must assert her own voice and not be spoken for. However, in brief, feminism in the West could be traced to Virginia Wolf's publication of A Room of One's Own (1919). This book explains the problems the woman encounters in a social structure constructed by the man. This book encouraged later writers like De Beauvoir whose book The Second Sex (1949) asserts that the male dominated society merely defines the woman as "the other". The 1960s political movements led to the greater rise in female writings that explore the female character with a view to asserting her individuality.

\section{The Rise of the Nigerian Feminist Novel}

Feminism in Nigeria is of a different mode and perspective compared to the Western brands of feminism. The differences in ideological perspectives have accounted for the many strands of feminism in Nigeria. These strands include womanism, motherism, stewanism, femalism. But the dominant one has been womanism. In spite of the different strands, one thing binds them together: the achievement of the common goal of liberating the Nigerian woman. Womanism became the dominant strand of African feminism when suddenly most Nigerian feminists came to terms with the fact that the radical and militant nature of Western feminism was out of place in Africa. This according to Aduke Adebayo(1996:4) "while accepting the emancipatory nature of feminism, the African feminist has discarded it violent and militant approach ... in carrying out their project the African feminist writer and critic were combative for justifiable reason". The African feminists have rejected those aspects of Western feminism that tend not to agree with African values.

Accordingly, as the African woman discards the radical aspect of Western feminism, she accepts or evolves a concept which accommodates the man. This concept is womanism. Womanism, according to Elizabeth Ogini (1996:14) "... recognizes that the needs of the black woman are not the same as those of the white woman, while 
equally affirming that the African woman has passed through a chain of oppressions under the system of patriarchy". One thing is clear here: the needs of the Western woman differ from those of the African woman. As Ogini puts it, "womanism desires that the man and the woman should be in harmony in the home and in the society at large" (Ogini:15). This contrasts the Western idea, where feminist writers and critics who argue that the woman does not need the man. Marriages in the West could be contracted and children may not be part of it. Some call for lesbianism. For instance, Barbara Smith calls for women to learn to get sexual satisfaction outside the man. One has to acknowledge the declaration of Ogini that "the womanist believes that the man and the woman have complementary roles of relationship" (Ogini:16). The African tradition abhors a man or woman being alone, and children are seen as fruits of marriages. Infertility in either spouse is seen as society's tragedy. Alkali(1986:120) The Stillborn, shows the heroine Li returning to her husband, Habu Adams, who is crippled and says: "side by side, we shall learn to walk again". Similarly Man's inability to have children is viewed as a symbol of human failure. Ogini(1996:18) further explains that:

Womanism is a movement that celebrates the woman's strength as a pillar, the strength that brings blackmen to recognize and compromise for harmonious co-existence of both sexes. Womanism is a special culture that reminds men with special indication that without woman's full involvement in the system with the man is incomplete in action as well as in achievements.

This has been the strength of the Nigerian female writers and critics in the past three decades.

Iniobong Uko (2004:9-10) argues that womanism "consists of a critical evaluation of the diverse levels and modes of relationship, a challenge of the status quo and a confrontation of the daily realities of women and women's oppression". Uko further argues that the tenet of womanism is to confront the realities of the African woman's oppression. The African woman is no more the docile type; she is assertive and at the same time acknowledges her male counterpart. There is a feminist theory in the Nigerian novel. Because of its non-militant approach and its submission to complementarity and harmonious co-existence with the man, this strand of feminism is womanism.

The Nigerian feminist novel came as a reaction to counter the negative image of the woman as presented in male-authored works. The image of women in male-authored works has been conditioned by male ambition. It therefore becomes the burden of the woman to create a parallel character to correct these ills against the woman. The Nigerian male novelist has created the woman as a femme fatale, the source of sorrow to man. Ihuoma, in Elechi Amadi's The Concubine, may be such as the archetype of Helen of Troy who because of her beauty, brings sorrow to men. The woman in male-authored works is voiceless. She exists not as a woman, but as mere extension of the man. She has no power of her own. The society which is governed and conditioned by the man has placed limitations on her. In some societies women under menstruation are seen as taboo, they are not allowed to touch spiritual objects for fear of defiling them or making them lose their efficacy. Rose Acholonu (1994:38) argues that men's way of presenting the woman in the literature carried from the folk tradition. She argues that female characters are treated as slaves. She describes Okonkwo as "a typical tyrant" (Acholonu: 40) who rules and directs his wives in the manner of a cattle herdsman" (Acholonu: 40). Okonkwo's tyrannical life makes his "wives live in awe of him" (Acholonu: 40). Acholonu goes further to examine Ekwensi's criticism of Jagua in Jagua Nana. She laments that in this novel, "we see the final debasement of the woman" (Acholonu: 41) and Ekwensi has presented in Jagua a "female creature devoid of virtue... a veritable epitome of a degraded female" (Acholonu:41). In her own opinion, by creating such a debased female, Ekwensi "seems to derive some sadistic pleasure from Jagua's suffering and humiliation" (Acholonu: 41).

In the feminist novel in Nigeria, the searchlight in literature has been turned on the wholesome woman who has attracted to herself recognition and acceptance. The feminist novel traces the female journey from ignorance and naivety to experience and selfhood. She now carves a name for herself. She is no longer defined by the man, but rather defines her role in the society. This is seen in the creation of assertive female characters by feminist novelists. Contrary to the Ekwefis of Achebe's creation, Simi of Soyinka's creation, Jagua of Ekwensi's, Ihuoma of Amadi's creation, we now have characters like Amaka in Nwapa's One is Enough, Debbie of Emecheta's Destination Biafra, Adah in Second Class Citizen and others. Emilia Oko(1994:72) has declared that "the Nigerian female writers have helped to redeem the uneven balance of male writers' characterization of women as adjunct not as selves". She lampoons Oladele Taiwo's position on Nwapa's characterization of Amaka. Oko argues that from the position of Taiwo, it shows that male critics are "lacking in critical generosity" (Oko:71).

Oko then advises that the male "literary critic must exercise judicious control over the prejudice of his sex" (Oko:72). She later sounds a little ironical when she argues that Nwapa "is creating credible women with credible 
weakness"(Oko:72). One thing Taiwo is questioning is the rationality or the morality in a woman seducing an ordained priest.

The Nigerian feminist novel has shown much commitment to the cause of the woman. Nwapa started this as a pathfinder of the feminist novel in Nigeria. Nwapa's heroine Efuru in Efuru refused to allow tradition to stand between her and her love by marrying without a bride price. She shows the assertiveness of the female voice. She launched the woman into commercial economy as a means of economic independence. Imo Eshiet (1997:24-5) explains that "... unlike most previous Nigerian novels where women are depicted as supreme and peripheral elements, in Nwapa's Efuru, the dominance and proliferation of the female character is unmistakable". This dominance and proliferation of female characters is seen clearly in One is Enough, in which Amaka leaves no stone unturned in her quest for independence. She does not allow her failed marriage with Obiora mar her sense of vision. She moves to Lagos where she discovers and benefits from the feminist philosophy of sisterhood as a sine qua non for female liberation.

Also, Emecheta's creation of the woman stands out alive. Her character like Nko in Double Yoke, Debbie, Akunna, Adah, Ogbanje Ojebeta all explode male myths. As Oko puts it, these women may have lost physical purity, but spiritually they are pure. Debbie broke the male myth and joined the army to participate actively in the war contrary to the view that such professions were exclusively for the men. The woman is no longer limited in space by marriage, Grace Okereke (1994:83) points out "in Double Yoke and Destination Biafra, Emecheta goes beyond protest to show woman rising above her limitations successfully, mapping out survival strategies and achieving independence and fulfillment outside marriage". The earliest feminist novels like Efuru, The Joys of Motherhood, Idu seem to have limited the woman's space to marriage, but the new novels locate the women revolting against the status quo and competing with the men in politics most often manipulating the man to achieve her aim.

Okereke (1994:49) also explains that in Destination Biafra:

Emecheta carves out a new role for women in the destiny and survival of a nation. By creating a self assertive politically-informed heroine like Debbie Ogedengbe, Emecheta has successfully taken woman from the periphery of Nigerian politics and made her an active agent of history...

The novels of Zaynab Alkali break the barriers of tradition. In The Stillborn where Li expresses her ascetic vision, Alkali explores the true feminism of complementarity. In The Virtuous Woman, Alkali explores the theme of education as the means of female liberation. In both novels, she uses the journey as a motif through which the woman moves from ignorance to experience and selfhood. The relationship between Laila and Nana Ai, Li and Faku shows the theme of female friendship. The journey motif is affirmed by Theresa Njoku (1994:178) when she argues that "The journey motif is central to both The Stillborn and The Virtuous Woman".

The novels of Ifeoma Okoye also have shown some of the skills of a feminist writer. But it is only Behind the Clouds (1981) that can stand out as a true feminist novel, though critics have shown that the heroine in Behind the Clouds, is assertive and has ascetic vision. This position appears to be a misreading. Ije, can best be situated within the womanist vision. Ije is a good wife, compared to other female characters like Mama, her mother in-law, Beatrice and Virginia. The womanist vision accommodates the man. Dozie declares that "Too well, I owe my success to business venture to her. I don't know what I would have done without her" (37). This is the womanist position that the man and the woman complement each other. For Achufusi to argue that Ije's assertiveness lies in her ability to move out of the house when she could not stand the evil ways of Virginia, and the docile attitude of Dozie is out of place because when Dozie realizes himself he returns begging, and Ije forgives him. Achufusi also contradicts herself when she says Ije is assertive but not a radical. Charles Nnolim's position on the novelistic vision of Okoye in Behind the Clouds is worth noting. Nnolim (1994:32) argues that the novel is an adolescent novel and not an adult one. According to him, "All the characters of Ifeoma Okoye are secondary interpretations" (Nnolim:33), and this accounts for the novel being an adolescent novel.

Another female novelist in Nigeria who has made her mark in the Nigerian literary scene is Akachi Ezeigbo. She has published three novels which include, The Last of the Strong Ones (1996), House of Symbols (2001), Children of the Eagle (2002). In these novels, Ezeigbo attempts to reconstruct history and locate women in specific space in the nation's history. For instance, the heroine in House of Symbols, Eaglewoman asserts her individuality early enough in the novel, Ezeigbo portrays her as a partner in the business of marriage. Ezeigbo uses this woman to portray the role women played in the making of Nigeria's history. Her women stand in contrast with the women of Achebe's novels who are passive. Eaglewoman joins a political party and is elected a deputy. She participates actively in the politics of Umuga and Osai without upsetting her marriage. Ezeigbo makes a strong statement here about the 
Nigerian politics and at the same time echoes that the woman can achieve fulfillment in life and at the same time remain a dutiful wife. She makes a clarion call to all women to transcend their limitations in marriage and participate actively in politics.

The Nigerian feminist novel has continued to grow, with young voices coming on stage. Among them are Fumilayo Adegbite's, Bonds of Destiny (1993) and Echoes of Yesteryears (1998), Chimamanda Adichie's Purple, Hibiscus (2003), Sefi Atta's Every Thing Good Will Come (2005), Swallow (2008) and Martina Eteng's False Start (2004). These new novels explore the female predicament in a sexist society. These young writers have continued the trend introduced by the older writers. Though these writers may not be classified as committed feminists, their works continue to receive feminist critics' attention in reviews, conferences and learned journals.

\section{The Western Voice and Feminist Criticism of the Nigerian Novel}

Sabine Jell Bahlsen (1995:32) examines the novels of Flora Nwapa from the standpoint of the concept of mammy water, the image of the Nigerian woman and Igbo woman specifically. According to her, the image of the Igbo woman has been conditioned by the goddess of Oguta Lake in Nwapa's novels. She holds that this goddess means a great deal to the heroines in Nwapa's novels. Using the woman of the lake, Bahlsen argues that Nwapa has to "re-construct the myth of the idealized divine woman and voices her own concern for an ideal of womanhood". It is this divine woman that inspires her into the creative enterprise. She uses this medium to debunk the claim of woman being a femme fatale. She explores Nwapa's heroines like Efuru in Efuru, Amaka in One is Enough, Kate, Rose and Dora in Women are Different. Unlike Elechi Amadi's Ihuoma who brings men to their perdition, these women attract wealth to their friends. Amaka is a "powerful woman who is mobile" (Bahlsen:33). She posits that Nwapa's heroines are non-conformists (Bahlsen:34) which explains the divine and superhuman nature of womanhood (Bahlsen:34). The heroines are able to "transcend the norms" (Bahlsen:34), go into the storms of life. Efuru, for instance, ends up with a man who is not worthy of her love, etc.

Bahlsen uses the Western feminist approach to argue that "the heroine is superior to the men and dominates her spouse. Her husband cannot live up to her" (Bahlsen:3). This position does not agree with the African feminist stance of complementarity. African feminism accepts motherhood but Bahlsen argues that the "need and struggle for child care is detracting and the presence of children ... keeps their mother from concentrating on important conversation" (Bahlsen: 36). This position does not add credibility to Bahlsen's views. She prefers mere gossip to children. This is typical of Western feminism. After stating the debilitating influence of children in the family, she later contradicts herself when she says children are the greatest source of joy" (Bahlsen:36).

The tenet of Bahlsen's criticism does not derive much from the African experience. She applies Western standards on the Nigerian feminist novel. She argues that children are central in Nigerian marriages, as she puts it. "Igbo men and women are expected to have children, particularly male children...." (Bahlsen:36). Here she castigates the issue of male progeny. She also points out that a childless woman is indirectly ostracized from her society. This position is to give way to a more Western position as she declares that "children may interfere with a woman's business activities and threaten her financial independence, her success, and her career... children can trap a mother..." (Bahlsen: 37-8).

Brenda F. Berrian(1995:53) argues that through humour and conversation, Nwapa has invented the African woman and placed her within the global perspective of politics, commerce and independence. She argues that, what Nwapa does is to stimulate a serious probing of social and moral issues that confront the Igbo woman in her everyday life. Nwapa uses the Igbo women as a mirror to view the entire Nigerian women in traditional society. Berrian, in declaring her feminist stand in the Nigerian novel, argues that "the traditional village society emerges favouring and emphasizing the importance of men and de-emphasizing the role of women so that women garner only a subordinate status deeply rooted in their dual roles as mother and wife" (Berrian:53). This position always leaves the woman with no option other than to choose an alternative life-style outside marriage like the case of Amaka in One is Enough. The alternative place from the village is the city. Berrian's preference for the city life other than the village is also contradictory as she says, "the city does not offer the perfect solution" (Berrian:53). The conversations and responses by Nwapa's heroines define the new African woman. She is no longer the timid and docile type; she is outspoken. Berrian argues that in One is Enough, Nwapa's creation of female voices defines the pattern and structure of her novel. She argues that Nwapa empowers the female dialogue and gives them space while disproving the belief that the woman cannot exist. The women here do not merely exist as existential figures. They are full of life. Berrian blames the African woman for contributing to her own problem. She argues that mothers-in-law disturb otherwise peaceful domestic situations of couples like Obiora and Amaka. This position is Western. In Western marriages the 
mother-in-law exists as an outsider, but in Africa this is not so. One's wife could mean the family's wife, she could be loved and cared for by any member of the family. Her problem is a shared one. In case of childlessness it is not viewed as the problem of the couples alone but as that of the extended family problem.

Berrian also argues that Nwapa presents two women for scrutiny, one is Amaka, the other is her mother in-law. Her mother-in-law, an epitome of village authority, is autocratic, while Amaka a New woman resists what she regards as an intolerable interference into her intimate life. She refutes Obiora's claims that he is the man so must be obeyed in all things right or wrong. Amaka tells him "I am a woman" (Berrian: 26).

Nwapa's position or feminist stance is neither a total rejection of the man nor of marriage. According to Berrian, if the woman needs a man, it may be for nothing other than sexual pleasure. She says Amaka "takes Izu as her lover because he is able to give her sexual pleasure" (55). Berian further asserts that:

Operating in a world of fuzzy standards and boundaries as a consequence of a rapidly changing social environment, Nwapa nevertheless exhibits a firm understanding of the moral issues involved: the betrayal of trust; the insecurity of marriage and motherhood; the re-valuation and recentering of motherhood and the possibility that women can be economically and emotionally independent (Berrian:56).

It is this economic and emotional independence that Amaka seeks in Berrian's view. Hence, her choice of individual destiny outside of wifehood without casting aside the importance of being a mother constitutes the butt of Nwapa's humour and social evaluations (Berrian:57). During the bathroom fight, Amaka uses a hammer to hit back at Obiora on the chest. This, Berrian believes, leaves Amaka with only two choices, either to become docile and accept the blows or become hysterical. She compares Obiora's fall during the bathroom fight with the fall of Izu and argues that the second fall of Izu is a metaphorical fall from grace to grass. She then says "Amaka becomes the agent for Izu's disintegration... a kind hearted and well meaning man can succumb to female seduction and changes his regular habits when he loses control of his life" (Berrian:58). Berrian raises so many issues that beg for explanation. She refers to Amaka as a temptress who will not succumb or conform to static roles (Berrian: 59). Berrian further argues that Nwapa has not received favourable criticism because of "male biased criticism" (60). Oladele Taiwo (1987:154) has declared that Amaka is more of a prostitute. This has not gone well with female critics. Adewale Meja-Peace hits back at Taiwo saying "there is no intrinsic reason why her (Amaka's) lover should not be a priest". Berrian holds that Amaka has used "bottom power" (61), and this sexual bargaining "is central if a woman is to be financially prosperous" (61).

In her own view, Emilia Oko (1994:72) argues that "it is the mark of Nwapa's true female genius that at last she is creating credible women, with credible weaknesses and aspirations". The irony is that most feminist critics have not been able to establish the moral vision in Nwapa's heroine seducing an ordained priest. Oko calls it "credible weakness", Berrian calls it "bottom power", Meja-Peace says there is no reason why Amaka's lover cannot be a priest.

Berrian's position shows that in Western feminist view, marriage is a confinement for the woman. She argues that the woman has the right to be married or not. But the centrality of children in African marriage makes it different from the West, where children may be seen as intruders into the world of the woman. Berrian has employed the Western method in the criticism of the Nigerian novel. She examines the issue of romantic love and says there is nothing wrong with sex before marriage. And the woman must not be a virgin because she wants to please the man. She assumes that Nwapa must have been exposed to the Western concept of courtship, romantic love and monogamy...." (65).

It is wrong for Berrian to argue that Nwapa became aware of courtship because she was exposed to Western concept. These concepts have been there in African society and are practised in the African way.

Kenneth Little (1980:134-5) argues that the feminist vision in Nwapa's Efuru lies in the heroine's "conflict with traditional norms and the decision of Efuru to remain single on account of her inability to bear children marks her individuality. He points out that the first feminist movement in the novel is when Efuru elopes with a man "without bride wealth" (Little: 58). Though a man, he uses the feminist approach without much bias. He introduces such terms as "bride wealth", a term that has become a replacement for bride price which feminist critics argue ties the woman to the man and makes her a mere accessory to the man. Feminist critics from Africa argue that the bride price keeps the woman in perpetual servitude to the man. Little also observes that female characters in the African novel are stereotypes. Female novelists take up this challenge and attempt a reversal of the stereotype in their works. 
Katherine Frank (1987:15) has been one of the most vocal voices in the criticism of the Nigerian feminist novel. According to her, "until recently most African novels have been written by men". And in these novels, "female characters were shadowy figures who hover on the fringes of the plot"(Frank:15). Her approach is with Western feminism, which is radical as she urges the African woman to carve out a destiny for herself, one which could 'be destiny with vengeance" (Frank15). In bold terms, she declares that the feminist novel in Nigerian should "embrace a situation of a world without men: man is the enemy, exploiter and oppressor" (Frank:15). Her Western orientation is carried into the criticism of the Nigerian novel. She sees the man as an enemy: a Western position. This position is contrary to African feminism where the man is seen as a partner. She urges the Nigerian woman to do away with the man. According to her there is no possibility of compromise or even a truce (Frank:16).

The militant position of Western feminism has not been embraced by African feminism which does not see the man as the enemy. Accordingly, Mary Modupe Kolawole (1997:13) explains that: "some radical feminists further advocate symbols". She quickly adds that, "But at the same time many also recognize the need to unite with the men" (Kolawole:13). It is this need to unite with the men that makes the militancy in Western feminism irrelevant to the African experience. Kolawole's views agree with the earlier views of Elizabeth Ogini (1996:15) that the extreme radical posture of Western feminism has led the African feminists to evolve a new brand called "womanism". This brand "desires the man and the woman should be in harmony in the home and in the society at large". This summarizes the position of African feminism.

While referring to Nwapa's One is Enough and Emecheta's Destination Biafra, Frank argues that "the feminists heroines in these books, all have the professional and economic will to live without men" (Frank: 16). Frank fails to note that the Nigerian women operate from a different cultural background. The heroines she mentions are economically independent, however they need the men. Amaka, for instance, keeps Izu because he gives her sexual pleasure. This means that though Amaka is economically independent, emotionally she is not.

She observes that the quest for personhood and fulfillment wavers in the novels because of the conflict between tradition and the quest for freedom and fulfillment. Tradition as they observe, has held the woman captive and for her to be liberated, she needs to confront tradition. In traditional African society barrenness is the worst affliction a couple can endure. Amaka bolts out of her marriage when she can no longer bear it, Efuru does the same. Frank argues that when a woman lacks reproductive power, she lacks all powers, political, social, economic and others. Frank calls on the Nigerian woman to seek economic power as the route to all powers and to total liberation.

Frank's position raises much concern for the Nigerian novel. She holds that "bottom power", "sexual bargaining", "prostitution" are all woman's instruments towards economic independence and selfhood. Amaka seduces Izu, yet she argues that Izu oppresses her, yet that Amaka has deliberately chosen her oppressor and she uses her bottom power for financial rewards. Similarly, Nko in Emecheta's Double Yoke uses her bottom power for academic rewards. The two novelists, Nwapa and Emecheta, have identified two major areas that their women must strike in order to be liberated: academic power and economic power. Nwapa and Emecheta do not hide their feelings: The common need for the woman to be free and this freedom should be won by whatever means.

Contrary to the position of African feminists that they are not at war with the men, Frank insists that it is not true when examined within the context of African woman's relation to their men. She argues that Destination Biafra has the problem of "evaluative criteria" (27). As a result, the novel is "aesthetically simplistic, empty and boring" (27). But she contradicts herself when she concludes that Debbie:

Is the most compelling example we have of the new African woman in Africa, she embodies a liberating ideal of potentiality of a rich creative and fulfilling future for African woman and it is an autonomous future to embrace, a future without men (Frank:149).

If the heroine is active and fulfilling, then the novel is not empty. As Okereke (1994:149) explains, Debbie represents "the new role Emecheta carves out for women in the destiny and survival of the nation". One may add that since Debbie tries to transform her femaleness, she dazzles the critical thinking of Frank who has been used to traditional characters like Idu and Efuru.

The basic tenet of Frank's argument is that women can live without men. This is a position of Western feminism. Many African critics have contested this position on the grounds that in Nigeria the man and the woman need each other. Among them is Chidi T Maduka(2003:229) who argues that "Feminism as an ideology can better be understood in the context of globalization which has virtually turned Africa into an economic, political and cultural satellite of Europe". 
Though Katherine Frank lampooned Nwapa and Emecheta for saying they are not feminists, her views and position demonstrate a clear disregard of African culture as she applies Western standards in the criticism of the Nigerian novel. Nwapa and Emecheta may have written about women, but these women are defined within the African cultural milieu. Even with Western education, the African woman has remained African in thought and ideology. Therefore it is out of place for Frank to think that these novelists have written a universal thesis. The African woman's situation is peculiar when compared to the Western woman.

Carole Boyce Davies (1990:2) is another feminist critic whose criticism of the Nigerian feminist novel has been quite revealing. She argues that for there to be a true feminist critic, there must, as a matter of expedience, be a true gender consciousness. This will clearly define the nature of feminism in Africa, both theoretically and ideologically. She argues that African feminist criticism is lagging behind because "the earliest critics of African literature were European academicians who communicated the Western male mode of creating and evaluating literature". In order to buttress these claims, she reviewed some of the criticism by some critics of African literature since its inception and came to the conclusion that women did feature prominently in these early works. Commenting on Philomena Steady's Black Woman Cross Culturally (1998), she argues that contrary to the view of many, that the African woman is actually a feminist, and the:

African brand of feminism includes: female autonomy... an emphasis on nature over culture, the centrality of children, multiple mothering and kinship; ... A number of traditional rights and responsibility of women allow her to conclude that the African woman is more a feminist than her European counterpart (Davies:6-7).

No matter what Steady and Davies hold, it is still difficult to believe that the African woman is much more a feminist than her Western counterpart. Davies later contradicts herself when she says "lack of choice in motherhood and marriage, oppression of barren women, genital mutilation, enforced silence on the women" (Davies:8), are forms of female subjugation in Africa. These forms of female subjugation are peculiar to African women and are not seen in the West.

Davies observes that there is a connection between African feminism and Western feminism because "both identify gender-specific issues and recognize woman's position intentionally as one of second class status" (Davies: 9). She then outlines what she considers as the theoretical models for the criticism of the feminist novel in Africa:

African feminist critics must take what is of value from both main-stream feminist criticism and African literary criticism keeping in mind that both are offshoots from traditional European literary criticism and in some cases its adversaries. The result then is not reduction but refinement geared specifically to deal with "the conceived and literary realities of African women's lives (Davies: 11).

If these are the issues that the feminist criticism of the Nigeria novels must look for, it therefore means that feminist writers must make visible the invisible woman, since the invisible and voiceless women exist only as tangential to men. Davies, like Alexander Pope, addresses both the writer and the critics. She argues that motherhood has remained a major theme in the Nigerian feminist novel. According to her, motherhood has been a source of joy and pain for the African woman. She draws her illustrations from Nwapa's Efuru and One is Enough and The Joys of Motherhood by Emecheta. Nwapa for instance "creates a world of women" (Davies: 249) and her novels have no feminist vision. She argues that in Efuru "Nwapa presents Efuru as a very assertive young woman who exercises her personal choice. She decides whom she wants to marry in defiance of the men of her family and goes to her husband without dowry" (Davies: 150). The assertiveness of Efuru brings out the feminist vision in this novel. Davies argues that the "woman's responsibility for self is a central concern in Efuru" (Davies: 152). But later she argues that "marriage was the beginning of her suffering ... being in a man's house means chores and subjugation..." (Davies:251).This betrays her earlier position that Efuru's marriage is based on romantic love. Nwapa has made motherhood central in her novels as Davies pointed out, but she failed to appreciate the fact that the idea of marriage and motherhood in the West differs from that in Africa. This issue as seen by Davies with Western sentiments beclouds her critical judgment.

The conception by Amaka and the subsequent birth of male twins which Davies describes as "immaculate conception" betrays some of the issues that feminist critics fight against, such as male progeny. Davies fails to note what Berrian describes as "the divine nature" of women in Nigerian novels. She argues that Nwapa imbues her heroines with divine nature through the woman of the lake "uhaniri. The woman of the lake gives motherhood to 
those who seek her. Amaka as a divine being cannot conceive from a man with no divine nature. She needs a divine seed to fertilize her. The priest who is divinely ordained and God's representative has to do the work. Critics like Emilia Oko, Ojo-Ade, Grace Okereke and Kolawole have attacked Oladele Taiwo for describing Amaka as a little prostitute. For instance, Oko says Nwapa "is creating credible women with credible weakness" (Oko: 72). Credibility and weakness contradict each other and do not in any way offer an alternative mode of analysis of the moral weakness which Taiwo points out. In as much as one does not agree with Taiwo that Amaka is a prostitute, one may not submit to Oko's view of "credible weakness" being held as a positive value. Amaka is a divine being who needs another divine being to assert her motherhood.

Davies views motherhood in Emecheta's novels as slavery. She says "Nnu Ego is both a slave to her children as much as a slave to tradition" (Davies: 253). She also argues that in The Joys of Motherhood, Emecheta has clearly shown "the tragedy of woman's existence when it remains circumscribed by motherhood alone" (253). Though there are some cases where African action appears negative, it is however, mere generalization and prejudice for Davies to argue that there is no distinction between the slave and the African woman in marriage. These views are born out of Western prejudices and an attempt to evaluate the African novel with Western criteria. One would agree with Davies that Nwapa and Emecheta represent the most striking force in the feminist novel in Nigeria. However, Davies theoretical models tend to bring Western feminist's values into the criticism of the Nigeria novel.

In the discussion of motherhood in the Nigerian novel Davies seems to be carried away by Western sentiment and the nature of motherhood in the West. The issue of motherhood is crucial when discussing the feminist novel in Nigeria. Davies may have employed Betty Friedan's Western concept of motherhood in the interpretation of the nature of motherhood in Africa.

Betty Friedan (1986:48) identifies the family as the new feminist frontier. To her, the family has been one single area that has held the woman captive for a very long time. She puts it thus: "I believe that feminism must, in fact, confront the family, albeit in new terms, if the movement is to fulfill its own revolution in modern society. Otherwise, it will abort or be put on history's shelf..."

Friedan believes that the family must be destroyed, if the woman is to be free, because women tend to lose their independence when they go into motherhood. In the West the woman's chances of making choices are there, but such opportunities are limited in Africa. Friedan is of the opinion that the woman has the right to bring a child into the world the way she wants it, and not by paying the terrible "price of isolation, from the rest of the world". Friedan argues that "surely that basic choice of motherhood is basic to their identity as women..." (Friedan: 89).

According to Davies, the woman's choice to have children and raise a family will automatically change her socio-biological reality. It will also mean that a woman who has chosen motherhood and profession must be a super woman. The Western feminists call on the woman to have total control over her reproductive process.

Western feminism which sees the family as an instrument of oppression advocates that the woman should employ whatever method she has at her disposal to dismantle it, not minding what people will say:

The enemies of feminism insist that the woman's move to equality, self-realization and her own power in society by destroying the family, which they feel is the woman's real locus power. Many families insist that the family was, and is the enemy, the prime obstacle to the woman's self realization (Friedan: 95).

The general thrust that runs through the feminist criticism of the Nigerian novel is the primacy of female liberation and the creation of gender consciousness among Nigerian women. As Davies observes, African women in the novel show:

various struggles for self definition. A character's ability to define herself is shaped both by her understanding of the boundaries by which society circumscribes her, and by her ability to transcend those boundaries and attain self actualization while remaining nonetheless within her society (Davies: 336 ).

This position seems to betray her earlier position that motherhood should be destroyed to bring the women to fulfillment. Here she holds that the Nigerian woman has been making concerted effort to transcend the two roles society ascribes to her.

Mineke Schipper(1987:155) also compares the image of the African woman to that of "colonial annexation". She sees the African woman as a victim of male domination. She argues that the African woman has been occupied and 
colonized by the man. She has been forced to a second class position as Schipper puts it:

She is deprived of her voice and like those colonized, she is called unreasonable and emotional, thus representing everything that rational men are not or do not want to be. Her situation and that of colonized people are linked in joint martyrdoms.

Schipper traces the despicable image of the African woman to the pre-colonial era of which she argues that "the concept of patriarchy has been put forward as a generalized item for the oppression of women" (157). The patriarchal system, according to her, is the breeding ground of woman's oppression. The patriarchal system makes many female writers shy away from the term feminism "often the term feminism is avoided by many African women because of its negative connotations and effect. There are women who actually associate the term with Western feminism: others avoid using it for strategic reasons" (Schipper: 163). Schipper uses postcolonial discourse to examine how the woman has emerged from the shadows of patriarchy to the new African woman, thereby putting forward a new discourse that the Nigerian feminist novel emerged strongly to shape the pattern of gender matters in the Nigerian novels. Though she does not anchor her analysis on any novel, her approach is meta-critical as she examines some of the texts and anthologies that exclude the works of women as she says "the issue of gender remained absent or insufficiently highlighted in both colonial literature and African texts by male authors" (Schipper:165).

\section{Conclusion}

The Western voice has helped to encourage the criticism of the Nigerian female novels. A number of these critics like Boyce Davies, Brenda Berrian, Katherine Frank and many others have made pronouncements on the Nigerian novel that have provoked Nigerian feminist critics to reply and put the African feminist novel in proper perspective. The criticism of Nigerian feminists came as a result of the way male critics have presented the woman and the militant approach Western critics adopt in evaluating the Nigerian feminists novel. Nigerian feminist critics have read the works of Western feminist critics such as Simone de Beauvoir's The Second Sex, Betty Friedan's The Feminine Mystique and The Second Stage, Germaine Greer's The Female Eunuch, Kate Mullet's Sexual Politics and other writers such as Elaine Showalter and Elisabeth Shousheller. What all these critics do is to raise gender consciousness. The Nigerian critic has taken what is good in Western feminism and blended it with what is good in African feminism.

In order to examine issues that relate to gender, the Nigerian feminist critic has tried to redefine the feminist theory taking into consideration that she must still remain essentially an African woman. Such alternatives as motherism, womanism, femalism, are all offshoots of the African critic's reaction to Western critics. Nigerian feminist criticism has produced notable feminist critics who now stand on the same pedestal as their Western feminist counterpart. Nigerian feminist critics have kept the flag of feminist criticism in Nigeria flying and it will continue to fly for a long time to come. These critics have explored all dimensions of the woman's life. Gender consciousness which has been the trademark of feminism has seen women being emancipated politically, academically, socially. We see women as leaders in positions of authority both in the economic and political spheres. The woman is fully aware of her rights and she uses her potentials well.

The feminist novel came as a counter-discourse aimed at redefining the woman and her place in society, raising such questions as Cynthia Ward (1996:74) puts it: "what is it like to be an African woman? How do you, and what do you think about men, motherhood patriarchy, culture"? These are some of the questions that this paper has been addressing within the context of the selected views from Western feminist critics.

This paper then concludes that Western feminist critic tends to transfer directly western ideology into Africa without taking into consideration that both operate from different cultural perspectives. It is also the position of this paper that a robust and holistic approach to gender studies should be taken particularly as it relates to African cultural values. African feminist critic has discarded those western values that tend to negate the very fiber of society and coined for her new terms that would properly define her being and existence; and still remain globally relevant

\section{References}

Acholonu, R. (1994). The female predicament in the Nigerian novel. I H. Chukwuma (Ed.), Feminism in African Literature: Essays on Criticism. (pp. 38-52). Enugu: New generation books.

Achufusi, G. I. (1994). Female individuality and assertiveness in the novels of Ifeoma Okoye. In H. Chukwuma (Ed.) 
Feminism in African literature: essays on criticism. (pp. 159-75). Enugu: New generation books.

Adebayo, A. (1996). Introduction. In A. Adebayo (Ed.). Feminism and black women's creative writing: Theory, practice and criticism. (pp. 1-9) Ibadan: AMD Publishers.

Bahlsen - J. S. (1995). The concept of mammy water in Flora Nwapa's novels. Research in African literature, 26(2), $30-41$.

Berrian, B. (1990). The reinvention of woman through conversation and humor in Flora Nwapa's One is enough. Research in African literature, 26(2), $52-67$.

Bressler, C. (1994). Literary criticism: An introduction to theory and practice. New Jersey: Prentice Hall

Davies, B. C. (1995). Feminist consciousness and African literary criticism. In C.B. Davies \& Graves A. A (Eds.) Ngambika: Studies of women in African literature. (pp.1-23) Trenton: African World Press.

Davies. B. C. (1990). Motherhood in the works of male and female Igbo writers: Achebe, Emecheta, Nwapa and Nzekwu. In C.B. Davies \& Graves (Eds.) Ngambika: Studies of women in African literature. (pp. 241-56). Trenton: African World Press.

de Beauvoir, S.(1972). The second sex. Harmondsworth: Penguin.

Eichler, M. (1980). The double standard: A feminist critique of feminist social science. London: Croom Helm.

Eshiet, I B. (1997). Flora Nwapa as a destructive pathfinder in a male dominated literature. In E. Eko,0gu, J.N.\& Oko E.(Eds.). Flora Nwapa: Critical perspective. (pp.21-32). Calabar: Calabar University Press.

Fiorenza, S. E. (1998). Sharing her word: Feminist biblical interpretation in context. Boston: Beacon Press.

Frank, K. (1987). Women without men: The feminist novel in Africa. African literature today, 15, 14 - 34.

Friedan, B. (1986). The econd stage. New York: Summit books.

Gubar, Susan. (1985). The blank page and The issue of female creativity. In E Showwalter (Ed.) The new feminist criticism. (pp. 292-313). New York: Pantheon books

Humm, M. (1986). Feminism criticism: Women as contemporary critics. Sussex: The Harvester press.

Kolawole, M M. (1997). Womanism and African consciousness. Treton: African world press.

Kolodny, A. (1985). A Map for eading: Gender and the interpretation of literary text. In Elaine Showalter. (Ed.). The new feminist criticism. (pp. 47-62). New York: Pantheon books.

Little, K. (1980). The Sociology of urban woman's Image in African literature. London: Macmillan.

Maduka, T. C. (2003).Feminism and the Nigerian female critic: A Meta-critical statement In Austin Akpuda (Ed.). Reconstructing the canons: Festschrift in honour of Professor Charles Nnolim.(pp. 227-42). Owerri: Treasure books.

Mamonova, Tatyana. (1984). “The Femmist Movement in the Soviet Union”. Women and Russia: Femmist Writing from Soviet Union. Ed. Tatyana Mamonova. Boston: Beacon Press.

Millett, K. 1971). Sexual politics. London. Sphere books.

Mineke, S. (1996). Emerging from the shadows: Changing patterns in gender matters. Research in African Literature, $27(1), 155-71$.

Mineke, S. (1987). Mother Africa on a pedestal: The male heritage in African literature and criticism. African literature today, 15, 36-54.

Myers, K. (1988). Towards a feminist erotica. In H.Bolmson, Visibly female: Feminism and art today. (PP. 283-96). New York: University Book.

Njoku, T. (1994). Personal identity and the growth of the Nigerian woman in Zynab Alkali's The stillborn and the Virtuous woman. In H. Chukwuma. Feminism in African Literature Essays on criticism. (pp. 178-88). Enugu: New generation books.

Nnolim, C. (1994). A house divided: Feminism in African literature. In (Ed.) Helen Chukwuma. Feminism in African literature Essay on criticism. (pp. 248-61). Enugu: New generation books

Ogini, E. (1996). Feminism then and now: A historical perspective. In A Adebayo. (Ed.) Feminism and black women's creative writing: Theory, practice and criticism. (pp. 11-20) Ibadan: AMD Publishers. 
Okereke, G (1994). Commitment to the feminist ideology in the novels of Buchi Emecheta. Ndunode: Calabar journal of humanities, 1(1), 80-92.

Okereke, G. (1994). The Nigerian civil war and the female imagination: Buchi Emecheta's Destination Biafra. In H. Chukuwuma (Ed.) Feminism in African literature: Essays on criticism. (pp. 144- 58). Enugu: New generation books.

Oko, E. (1994). Issues of gender images of women in Nigerian writings. Ndunode Calabar journal of humanities, $1(1), 66-79$.

Orenstein, F. G. (1988). The reemergence of the archetype of the great goddess in art by contemporary women. (Ed.). H. Bolmson. Visibly female: Feminism and art today. (pp.158-70). New York: University book.

Showalter, E. (1985). The feminist critical revolution. In E. Showalter (Ed) The new feminist criticism.(pp. 1-17). New York: Pantheon books.

Smith, B. (1985). Toward a black feminist criticism. In E. Showalter (Ed) New feminist criticism: essays on women, literature and theory. (pp. 168-85). New York: Pantheon books.

Tatyana, M. (1980). The feminist movement in the Soviet Union. In T. Manomova (Ed.) Women and Russia: Feminist writings from the Soviet Union. (pp.xiii-xxiii). London: Sheba feminist press.

Uko, I. (2004). Gender identity in the works of Tess Onwueme. Trenton: African world press.

Ward, C. (1996). Reading African women readers. Research in African Literature, 27(2), 78- 86.

Wolf, N. (1997). Promiscuities: The secret struggle for womanhood. New York: Random press. 